\title{
Sistem Pakar Juru Pemantau Jiwa (Jumanji) Berbasis Web Dengan Metode Forward Chaining
}

\author{
Muhammad Adil ${ }^{1}$, Henny Leidiyana ${ }^{2,{ }^{*}}$ \\ * Korespondensi: e-mail: henny.hnl@bsi.ac.id
}

1 Program Studi Teknik Informatika, STMIK Nusa Mandiri, Jl. Kramat Raya No.18, RT.5/RW.7, Kwitang, Kec. Senen, Kota Jakarta Pusat, Daerah Khusus lbukota Jakarta 10420, Telp (021) 31908575, e-mail: m.adil 86@yahoo.com

2 Program Studi Sistem Informasi, Universitas Bina Sarana Informatika, Jl. Kamal Raya No.18, RT.6/RW.3, Cengkareng Bar Kecamatan Cengkareng, Kota Jakarta Barat, Daerah Khusus Ibukota Jakarta 11730 ,e-mail: henny.hnl@bsi.ac.id

Submitted: 6 Maret 2020 Revised: 27 Maret 2020 Accepted: 17 April 2020 Published: 20 Mei 2020

\section{Abstract}

Through the mass media news is often found about how a family or community handles family members who have mental disorders by mounting, isolating, and even throwing them away. This shows that one of the things that causes the family to handle the problem inappropriately is the lack of information about diagnoses of mental disorders so that they take actions that could make the sufferer worse. The expert system designed by the writer here aims to produce an expert system that can be used by the general public. The system is made in such a way that it can be used easily to provide knowledge to the public about mental disorders and how to deal with it. With this expert system, families and even the surrounding community can take appropriate action if there are people with mental disorders in the vicinity. This expert system uses a method that is quite popular, namely Forward Chaining which is implemented in the form of a web-based application program. Application is made using the PHP programming language then testing based on the Black Box method

Keywords: Expert system, Mental disorder, Forward Chaining.

\section{Abstrak}

Melalui media massa sering dijumpai berita tentang bagaimana sebuah keluarga atau masyarakat menangani anggota keluarganya yang mengalami gangguan jiwa dengan cara memasung, mengucilkan, bahkan membuangnya. Ini menunjukkan bahwa salah satu hal yang menyebabkan keluarga kurang tepat dalam menangani permasalahan tersebut adalah kurangnya informasi tentang diagnosa gangguan jiwa sehingga mereka melakukan tindakan yang bisa jadi membuat penderita semakin parah. Sistem pakar yang dirancang penulis di sini bertujuan untuk menghasilkan sistem pakar yang dapat digunakan oleh masyarakat secara umum. Sistem yang dibuat sedemikian rupa sehingga dapat digunakan secara mudah untuk memberikan pengetahuan kepada masyarakat tentang gangguan jiwa dan cara menanganinya. Dengan adanya sistem pakar ini, keluarga bahkan masyarakat di sekitarnya dapat melakukan tindakan yang tepat jika ada penderita gangguan jiwa di sekitarnya. Sistem pakar juru pemantau jiwa ini menggunakan metode yang cukup populer yaitu forward Chaining yang diimplementasikan ke dalam bentuk program aplikasi berbasis web. Aplikasi dibuat menggunakan bahasa pemograman PHP kemudian dilakukan pengujian berdasarkan dengan metode Black Box.

Kata Kunci: Sistem pakar, gangguan jiwa, Forward Chaining.

\section{Pendahuluan}

Penerapan ilmu komputer dalam berbagai bidang saat ini sudah sangat luas. Mulai dari kalangan perusahaan sampai masyarakat tanpa disadari telah menyandarkan aktifitasnya pada peralatan yang berbasis aplikasi komputer. Bidang medis adalah salah satu dari sekian banyak bidang yang menjadikan computer sebagai bagian penting dalam kegiatan medis. Dalam KBBI, makna medis adalah termasuk atau berhubungan dengan bidang kedokteran. Bidang kedokteran yang menangani masalah penyakit bukan saja penyakit fisik tetapi juga jiwa. Di Indonesia khususnya, penderita gangguan jiwa menurut Konsultan Health Policy Unit, Setjen Kementerian Kesehatan, 
Trihono, pada Southeast Asia Mental Health Forum 2018 di Jakarta, Kamis (30/8), sebanyak 15,8 persen keluarga memiliki penderita gangguan jiwa berat yang diobati dan tidak diobati. Untuk menangani hal ini terjadi, maka dibutuhkan psikolog untuk mendiagnosa apa yang terjadi dan berkonsultasi dengan psikolog membutuhkan biaya yang tidak sedikit dalam setiap konsultasi sehingga keluarga bisanya menangani sendiri keluarganya yang mengalami gangguan jiwa. Permasalahan-permasalahan tersebut salah satunya dapat diatasi dengan cara membangun aplikasi sistem pakar diagnosa penyakit kejiwaan.

Sistem pakar ini sifafnya sama seperti seorang psikolog, yang berisi tentang pengetahuanpengetahuan didalam bidang psikologi yang diubah kedalam bentuk sebuah web. Sistem pakar untuk juru pemantau jiwa ini dapat membantu penderita yang mengalami gangguan kejiwaan ataupun masyarakat yang mengalami gejala-gejala penyakit kejiwaan.

Dengan memahami cara kerja sistem pakar yang meniru cara manusia dalam memecahkan suatu masalah spesifik, atas dasar pemikiran tersebut timbul suatu ide untuk membuat suatu sistem pakar yang diharapkan membantu memecahkan masalah dan mencari langkah yang tepat dalam mendiagnosa kejiwaan serta memberikan pengetahuan kepada orang lain tentang kondisi kejiwaan, sehinga diperoleh data untuk penanganan yang lebih cepat dan tepat.

\section{Metode Penelitian}

\section{A. Algoritma Sistem Pakar}

Setelah menyusun perancangan sistem pakar untuk juru pemantau jiwa seperti yang dijelaskan pada bab sebelumnya, maka dilanjutkan pada implementasi program. Hal ini dimaksudkan untuk menerapkan dan memberikan penjelasan mengenai langkah-langkah dalam menjalankan program yang dibuat.

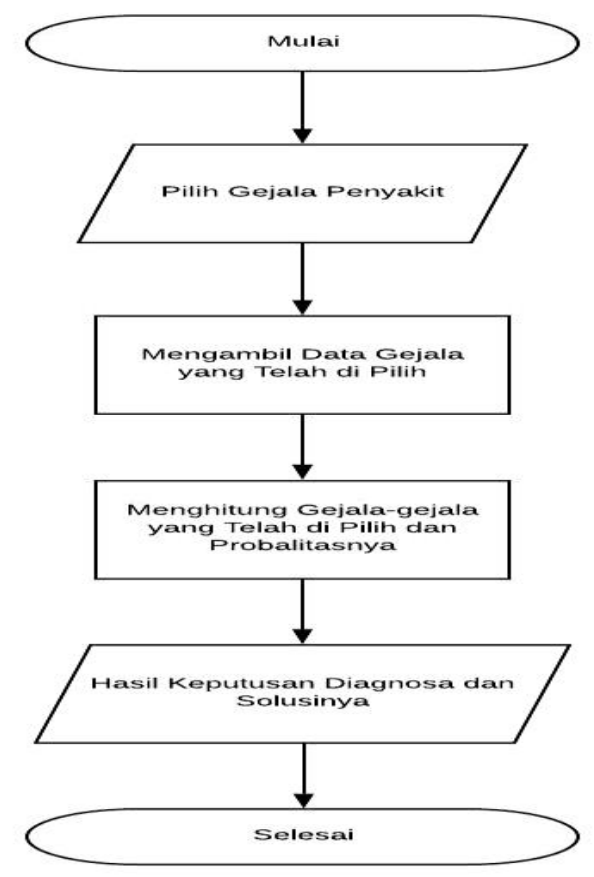




\section{B. Basis Pengetahuan}

Dalam pengembangan sistem pakar ini, penulis menggunakan tabel yang dikembangkan oleh pakar dalam mengambil kesimpulannya. Dimana fakta-fakta dari variabel yang menjadi parameter pakar dalam merangkum kesimpulan yang diambil sehingga menghasilkan kesimpulan yang objektif.

\section{Tabel Pakar}

Tabel pakar merupakan fakta-fakta yang diperoleh dari pakar, ilmu pengetahuan, penelitian dan pengalaman-pengalaman mereka dalam mengidentifikasi gejala penyakit kejiwaan. Dibawah ini terdapat beberapa tabel dasar pengetahuan dari program sistem pakar juru pemantau jiwa yang disertai dengan kode penyakitnya, serta tabel gejala yang ada pada sistem pakar ini.

Tabel 1. Tabel Penyakit Gangguan Jiwa

\begin{tabular}{|c|c|}
\hline Kode Penyakit & Nama Gangguan \\
\hline $\mathrm{P} 1$ & Demensia \\
\hline $\mathrm{P} 2$ & Amnesia \\
\hline P3 & Gangguan akibat alkohol dan zat \\
\hline P4 & Skizofrenia \\
\hline P5 & Skizofrenia paranoid \\
\hline P6 & Skizofrenia katatonik \\
\hline $\mathrm{P} 7$ & Skizofrenia terdisorganisasi \\
\hline P8 & Skizofrenia residual \\
\hline P9 & Skizotipal \\
\hline P10 & Gangguan waham menetap \\
\hline $\mathrm{P} 11$ & Gangguan waham induksi \\
\hline P12 & Depresi \\
\hline $\mathrm{P} 13$ & Siklotimia \\
\hline $\mathrm{P} 14$ & Distimia \\
\hline P15 & Gangguan Panik \\
\hline P16 & Gangguan Cemas menyeluruh \\
\hline $\mathrm{P} 17$ & Gangguan Neurosis Depresi \\
\hline P18 & Gangguan campuran ansietas dan depresi \\
\hline P19 & Gangguan obsesi-kompulsi \\
\hline $\mathrm{P} 20$ & Reaksi stress berat \\
\hline $\mathrm{P} 21$ & Gangguan penyesuaian \\
\hline P22 & Gangguan disosiatif \\
\hline P23 & Gangguan somatoform \\
\hline P24 & Gangguan Kepribadian khas \\
\hline P25 & Gangguan Kepribadian paranoid \\
\hline P26 & Gangguan kepribadian emosional tak stabil tipe impulsive \\
\hline P27 & Gangguan kepribadian anti social \\
\hline P28 & Gangguan kepribadian schizoid \\
\hline P29 & Gangguan kepribadian anankastis \\
\hline P30 & Gangguan kepribadian histrionic \\
\hline P31 & Gangguan kepribadian dependen \\
\hline P32 & Gangguan kepribadian narsisistik \\
\hline P33 & Gangguan kepribadian menghindar \\
\hline P34 & Penyakit tidak ditemukan \\
\hline
\end{tabular}

Sumber: Hasil Penelitian (2019) 
Pada Tabel 1 menjelaskan tentang kode gejala dan nama penyakit gangguan jiwa, terdiri dari 34 kode jenis penyakit gangguan jiwa.

Tabel 2. Tabel Gejala Gangguan Jiwa

\begin{tabular}{cl}
\hline Kode Gejala & \multicolumn{1}{c}{ Nama Gejala } \\
\hline G1 & Daya ingat jangka pendek terganggu \\
\hline G2 & Orientasi memburuk \\
\hline G3 & Gangguan persepsi \\
\hline G5 & Intelektual menurun \\
\hline G6 & Perubahan afek dan tingkah laku \\
\hline G7 & Pasien perduli terhadap akibat tingkah laku \\
\hline G8 & Ketidakmamplan mempelajari hal baru \\
\hline G9 & Orientasi orang tidak terganggu \\
\hline G10 & Daya ingat jangka panjang tidak terganggu \\
\hline G11 & Daya ingat segera masih baik \\
\hline G12 & Perubahan kepribadian \\
\hline G14 & Apatis \\
\hline K15 & Kurang inisiatif \\
\hline G16 & pengingungan \\
\hline G17 & beraktifitas mencari zat \\
\hline G19 & $\begin{array}{l}\text { Mengalami sakau pikiran diri sendiri yang berulang, walaupun isinya } \\
\text { sama tapi kualitasnya berbeda }\end{array}$ \\
\hline G20 & Terbuka tentang isi pikirannya \\
\hline G21 & $\begin{array}{l}\text { halusinasi yang dikendalikan oleh pemikiran yang } \\
\text { bersifat mistik atau mukjizat }\end{array}$ \\
\hline G22 & $\begin{array}{l}\text { halusinasi suara yang berkomentar (halusinasi } \\
\text { auditorik) }\end{array}$ \\
\hline G23 & $\begin{array}{l}\text { halusinasi menetap yang menurut budaya sekitar } \\
\text { tidak wajar }\end{array}$ \\
\hline h24 & $\begin{array}{l}\text { halusinasi menetap dari panca indera apa saja yang } \\
\text { menetap }\end{array}$ \\
\hline
\end{tabular}

Sumber: Hasil Penelitian (2019)

Pada Tabel 2 menjelaskan tentang kode gejala dan nama gejala gangguan jiwa, terdiri dari 24 kode jenis gejala gangguan jiwa. Sedangkan Tabel 3 menjelaskan tentang table solusi gangguan jiwa terdiri 3 solusi gangguan jiwa untuk 3 kode penyakit.

Tabel 3. Tabel Solusi Gangguan Jiwa

\begin{tabular}{|c|c|}
\hline $\begin{array}{c}\text { Kode } \\
\text { Penyakit }\end{array}$ & Solusi \\
\hline P1 & $\begin{array}{l}\text { Secara umum, terapi pada demensia adalah perawatan medis yang mendukung,member } \\
\text { dukungan emosional pada pasien dan keluarganya, serta farmakoterapi untuk gejala yang } \\
\text { spesifik. Terapi sistomanik meliputi diet, latihan fisik yang sesuai, terapi rekreasional } \\
\text { dan aktivitas, serta penanganan terhadap masalah-masalah lain. Sebagai farmakoterapi, } \\
\text { benzodiazepine diberikan untuk ansietas dan insomnia,antidepresan untuk depresi, serta } \\
\text { antipsikotik untuk gejala waham dan halusinasi. }\end{array}$ \\
\hline P2 & $\begin{array}{l}\text { Terutama ditujukan kepada penyakit yang mendasarinya. Pendekatan bersifat } \\
\text { suportif yang berkaitan dengan waktu dan tempat akan sangat membantu pasien dan } \\
\text { mengurangi rasa cemasnya. Setelah episode amnesia teratasi, beberapa jenis } \\
\text { psikoterapi (kognitif, psikodinamik, atau suportif) mungkin dapat membantu pasien. }\end{array}$ \\
\hline P3 & $\begin{array}{l}\text { Pendekatan pengobatan untuk penyalahgunaan zat bervariasi menurut zat, pola } \\
\text { penyalahgunaan, tersedianya sistem pendukung dan ciri individual pasien. Tujuan utama } \\
\text { pengobatan adalah abstinensi zat serta mencapai kesehatan fisik psikiatrik dan } \\
\text { psikososial. Pendekatan pengobatan awal dapat dilakukan dengan rawat inap atau rawat } \\
\text { jalan. Pengobatan rawat inap dindikasikan pada adanya gejal medis atau psikiatri yang } \\
\text { parah, suatu riwayat gagalnya pengobatan rawat jalan, tidak adanya dukungan psikososial, } \\
\text { atau riwayat penggunaan zat yang parah atau berlangsung lama. }\end{array}$ \\
\hline
\end{tabular}




\section{Rule Pakar}

Untuk mempresentasikan pengetahuan kedalam sistem digunakan metode kaidah produksi yang biasanya dituliskan dalam bentuk Jika-maka (if-then). Kaidah dapat dikatakan sebagai hubungan implikasi dua bagian yaitu premis (jika) dan bagian konklusi (jika). Apabila syarat premis terpenuhi maka bagian konklusi juga bernilai benar. Sebuah kaidah terdiri dari klausa-klausa, sebuah klausa mirip kalimat subjek, kata kerja dan objek yang menyatakan suatu fakta. Ada klausa premis dan klausa konklusi pada sebuah kaidah. Suatu kaidah juga dapat terdiri dari beberapa premis dan beberapa konklusi.

Tabel 4. Tabel Solusi Gangguan Jiwa

\begin{tabular}{|c|c|c|}
\hline Rule & If & Then \\
\hline 1 & G1, G2, G3, G4, G5, G6, G7 & $\mathrm{P} 1$ \\
\hline 2 & G1, G2, G8, G9, G10, G11, G12, G13, G14,G15 & P2 \\
\hline 3 & G16, G17, G18, G81 & P3 \\
\hline 4 & G19, G20, G21, G22, G23, G24, G25, G26, G27, G28, G29 & P4 \\
\hline 5 & G22, G30, G31, G32 & P5 \\
\hline 6 & G33, G34, G35, G36 & P6 \\
\hline 7 & G37, G38, G39 & P7 \\
\hline 8 & G30, G31, G40 & P8 \\
\hline 9 & G41, G41, G43, G44, G45, G46, G47, G48, G49 & P9 \\
\hline 10 & G50 & $\mathrm{P} 10$ \\
\hline 11 & G51, G52, G53 & $\mathrm{P} 11$ \\
\hline 12 & G1, G54, G55, G56, G7, G58, G59, G60 & $\mathrm{P} 12$ \\
\hline 13 & G64, G65 & $\mathrm{P} 13$ \\
\hline 14 & G54, G66, G67 & P14 \\
\hline 15 & G68, G69, G70, G71, G72, G73, G74, G75, G76, G77, G78, G79, G80 & $\mathrm{P} 15$ \\
\hline 16 & G82, G83, G84, G85 & $\mathrm{P} 16$ \\
\hline 17 & G56, G58, G86, G87, G88, G89, G90, G91,G92 & P17 \\
\hline 18 & G54, G82 & P18 \\
\hline 19 & G93, G94, G95, G96 & P19 \\
\hline 20 & G97, G98 & P20 \\
\hline 21 & G28, G54, G82, G97, G99 ,G100, G101, G102 & P21 \\
\hline 22 & G103 & $\mathrm{P} 22$ \\
\hline 23 & G104 & $\mathrm{P} 23$ \\
\hline 24 & G42, G105, G107 & P24 \\
\hline 25 & G108, G109, G110, G111, G112, G113, G114, G115 & P25 \\
\hline 26 & G116, G117, G118 & P26 \\
\hline 27 & G102, G119, G120, G121, G122, G123, G124 & P27 \\
\hline 28 & G28, G125, G126, G127, G128, G129 & P28 \\
\hline 29 & G130, G131, G132, G133, G134, G135, G136 & P29 \\
\hline 30 & G9, G137, 138, G139, G140, G141 & $\mathrm{P} 30$ \\
\hline 31 & G91, G142, G143, G144, G145, G146, G147, G148, G149 & P31 \\
\hline 32 & G150, G151, G152, G153 & P32 \\
\hline 33 & G154, G155, G156, G157, G158, G159 & P33 \\
\hline
\end{tabular}

Sumber: Hasil Penelitian (2019)

Pada Tabel 4 menjelaskan tentang 33 rule, If dan then dari solusi gangguan jiwa.

\section{Hasil dan Pembahasan}

Pada tahap ini akan dilakukan analisis terhadap kebutuhan - kebutuhan sistem dan perangkat keras terhadap aplikasi juru pemantau jiwa. Tahap Pertama, Analisis Kebutuhan Input yaitu Masukan dari aplikasi juru pemantau jiwa ini adalah sebagai berikut: 1) Data - data gejala dan 2) Data - data penyakit. Tahap Kedua, Analisis Kebutuhan Output, yaitu Keluaran dari aplikasi juru pemantau jiwa ini terbagi dua: 1) Pengunjung, Berupa tampilan halaman utama, konsultasi, hasil konsultasi. 2) Admin, Berupa halaman untuk mengelola data gejala, penyakit, aturan, dan laporan. Tahap Ketiga, Analisis Kebutuhan Proses, Proses yang dirancang yaitu menyediakan halaman utama bagi pengunjung, kemudian pengunjung dapat melakukan konsultasi dan melihat hasilnya. 
Admin dapat melakukan pengubahan atau penghapusan data gejala, penyakit, dan aturan. Admin juga dapat melakukan pengelolaan tehadap konsultasi yang masuk. Tahap Keempat, Analisis Kebutuhan Perangkat Keras, Spesifikasi komponen perangkat keras yang digunakan untuk pembuatan aplikasi ini adalah sebagai berikut: PC/Laptop dengan Prosesor core 2 duo, RAM 1 GB, VGA dengan memori $256 \mathrm{MB}$, Keyboard dan mouse sebagai piranti input, Monitor sebagai piranti output dan Harddisk. Tahap Kelima, Analisis Kebutuhan Perangkat Lunak, Perangkat lunak yang dibutuhkan pada pembangunan aplikasi adalah sebagai berikut: 1) Sistem operasi Windows 7. 2) Xampp, dan 3) Macromedia Dreamweaver.

Tampilan dari aplikasi sistem ini dijelaskan sebagai berikut:

1. Tampilan Halaman Utama

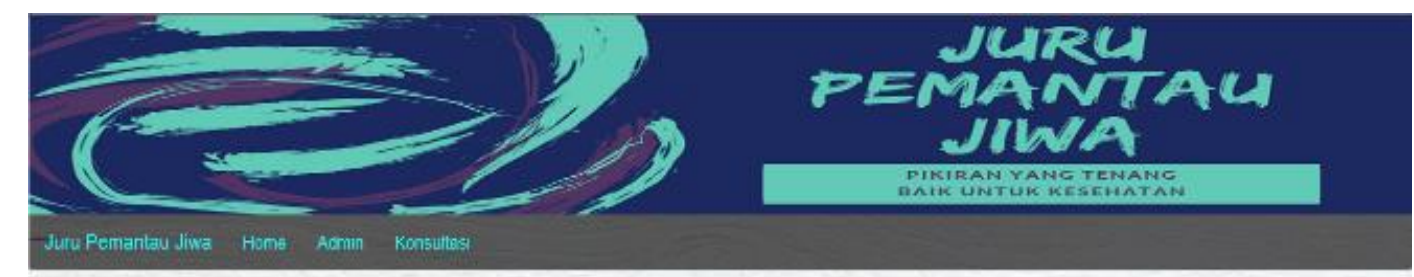

\section{PETUNJUK}

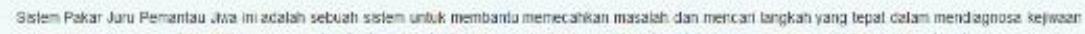

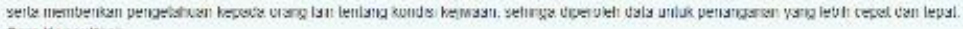
Cara Konsultensc 1 Kir Were Konsuth:

3 til inkem nom

Cckikt ge zya seual yang anda alem

4. Kik Proses

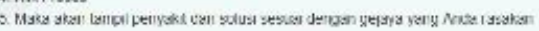

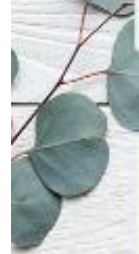

(n)

Kesehatan Jiwa: Mengapa Saya Harus Peduli?

Sumber: Hasil Penelitian (2019)

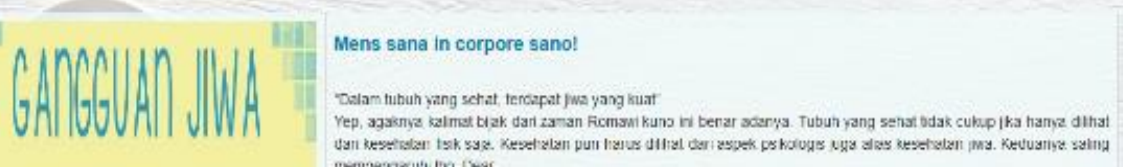

Gambar 1. Tampilan Halaman Utama

Tampilan halaman utama pada Gambar 1 adalah halaman utama dan pertama bagi pengunjung web. Jika pengunjung ingin melakukan konsultasi maka pilih Konsultasi pada menu bar.

2. Tampilan Halaman Konsultasi 

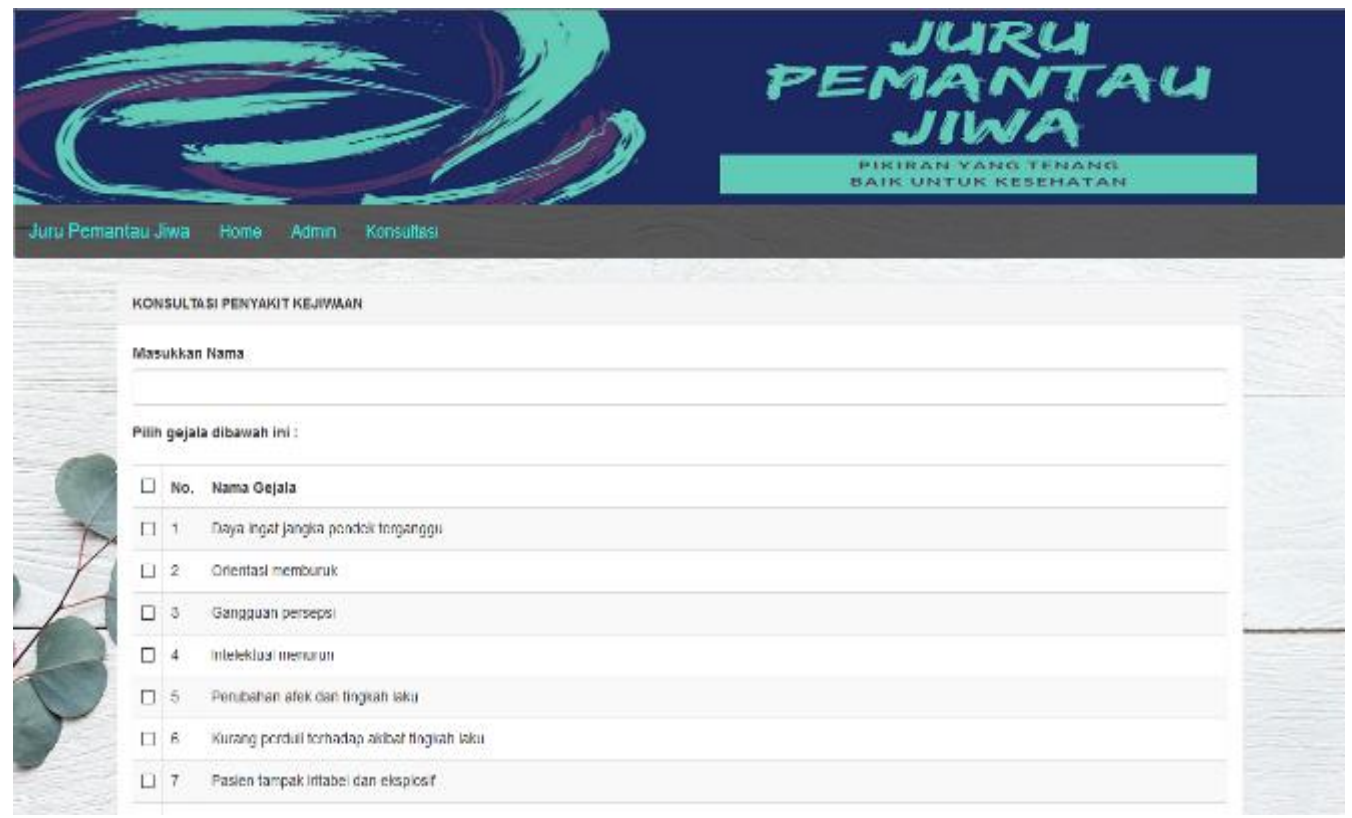

Sumber: Hasil Penelitian (2019)

Gambar 2. Tampilan Halaman Konsultasi

Gambar 2 adalah halaman konsultasi yang tampil setelah pengunjung memilih menu konsultasi. Di sini pengunjung mengisi gejala dengan cara mencentang pada bagian kiri gejala yang telah disediakan.

3. Tampilan Halaman Hasil Konsultasi

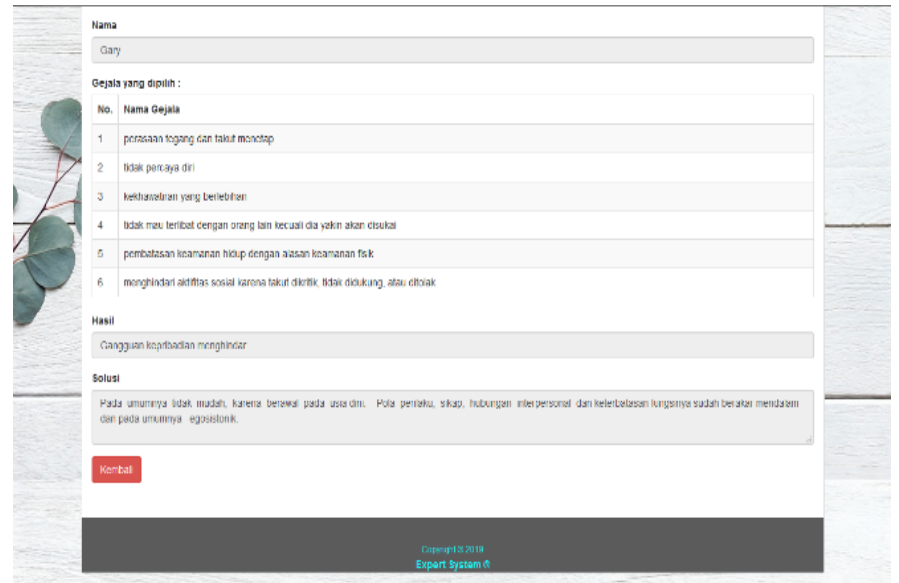

Sumber: Hasil Penelitian (2019)

Gambar 3. Tampilan Halaman Hasil Konsultasi

Setelah pengunjung mengisi gejala lalu melakukan submit maka hasil akan tampil seperti pada Gambar 3. Pada tampilan hasil, gejala yang telah diisi dan kesimpulan gangguan yang diderita akan tampil.

4. Tampilan Halaman Login 


\begin{tabular}{|c|c|}
\hline LOGIN & \\
\hline User Nam & \\
\hline admin| & \\
\hline Passworc & \\
\hline$\cdots \cdots$ & \\
\hline Submit & Exit \\
\hline
\end{tabular}

Sumber: Hasil Penelitian (2019)

Gambar 4. Tampilan Halaman Login

Gambar 4. adalah halama login admin. Yang bisa login adalah admin yang telah terdaftar. Di halaman ini admin memasukkan username dan password.

\section{Tampilan Halaman Gejala (Admin)}

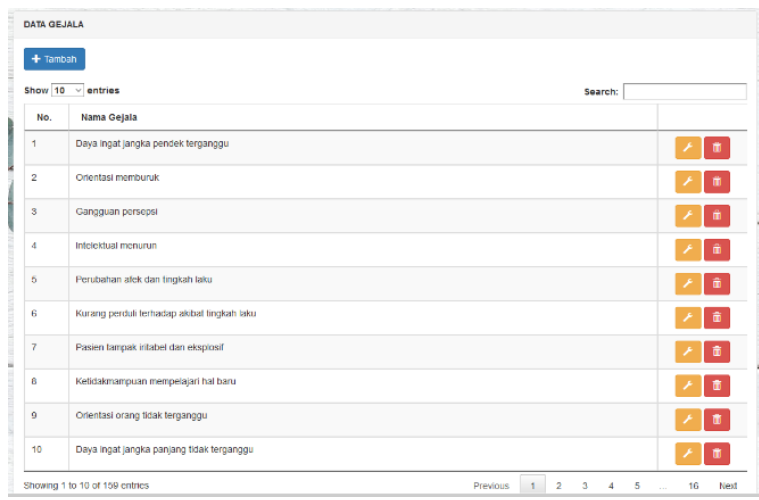

Sumber: Hasil Penelitian (2019)

Gambar 5. Tampilan Halaman Gejala (Admin)

Admin dapat melakukan perubahan gejala apabila diperlukan. Pada Gambar 5 terlihat bagian kanan ada menu untuk mengubah atau menghapus gejala.

\section{Tampilan Halaman Penyakit (Admin)}

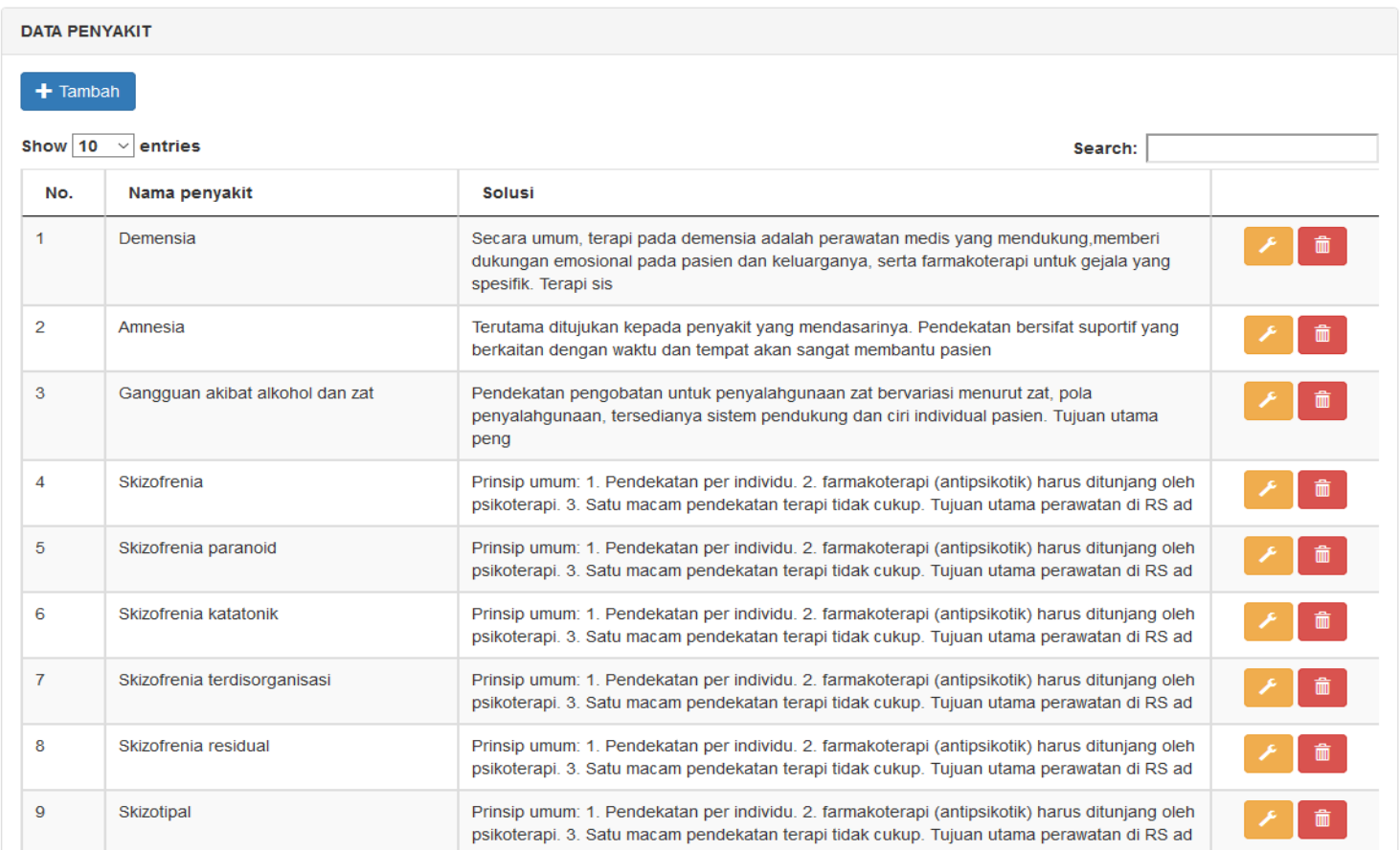

Sumber: Hasil Penelitian (2019) 
Gambar 6. Tampilan Halaman Penyakit (Admin)

Admin juga dapat melakukan perubahan penyakit seperti pada Gambar 6. Tampilannya hampir sama dengan halaman gejala.

7. Tampilan Halaman Aturan (Admin)

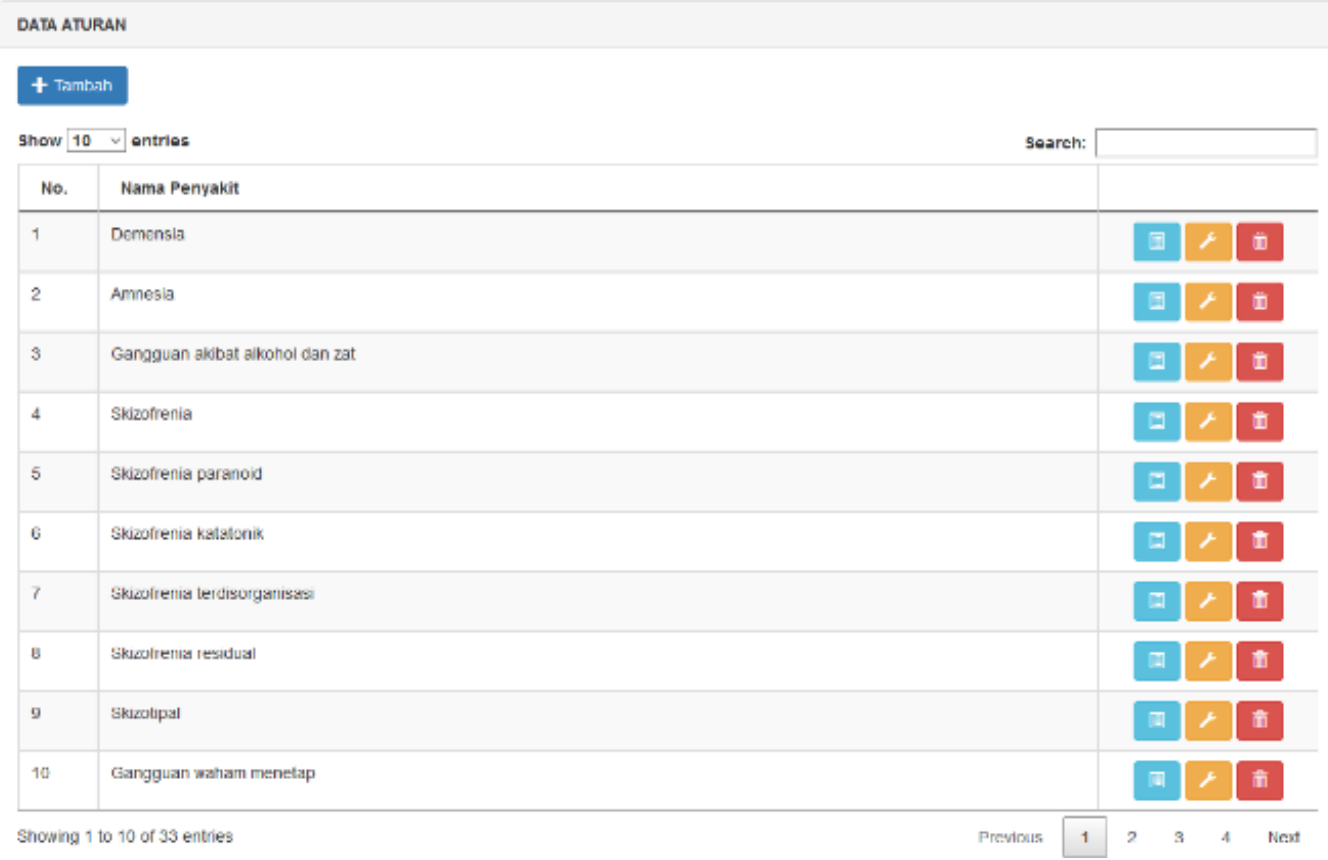

Sumber: Hasil Penelitian (2019)

Gambar 7. Tampilan Halaman Aturan (Admin)

Kemudian admin dapat melakukan pengelolaan aturan seperti pada Gambar 7.

8. Tampilan Halaman Konsultasi (Admin)

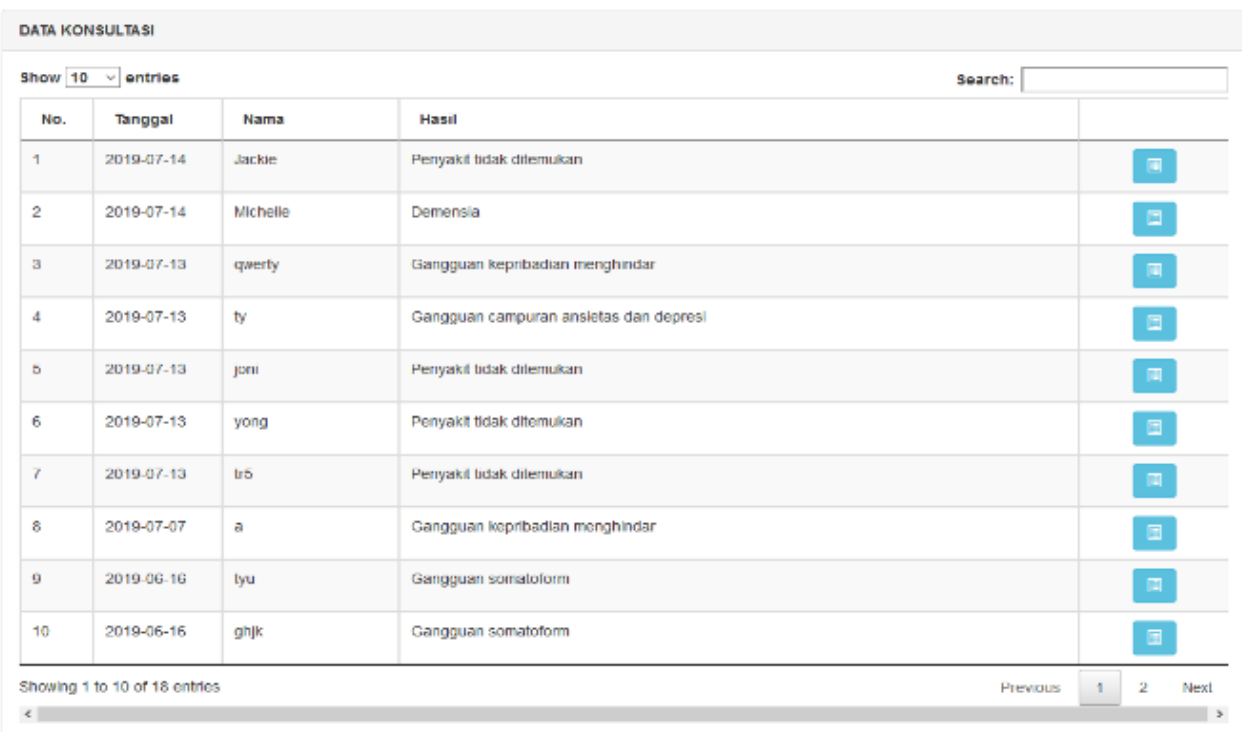

Sumber: Hasil Penelitian (2019)

Gambar 8. Tampilan Halaman Konsultasi (Admin)

Hasil konsultasi yang masuk ke dalam basis data dapat dikelola oleh admin seperti pada Gambar 8.

9. Tampilan Halaman Laporan (Admin) 


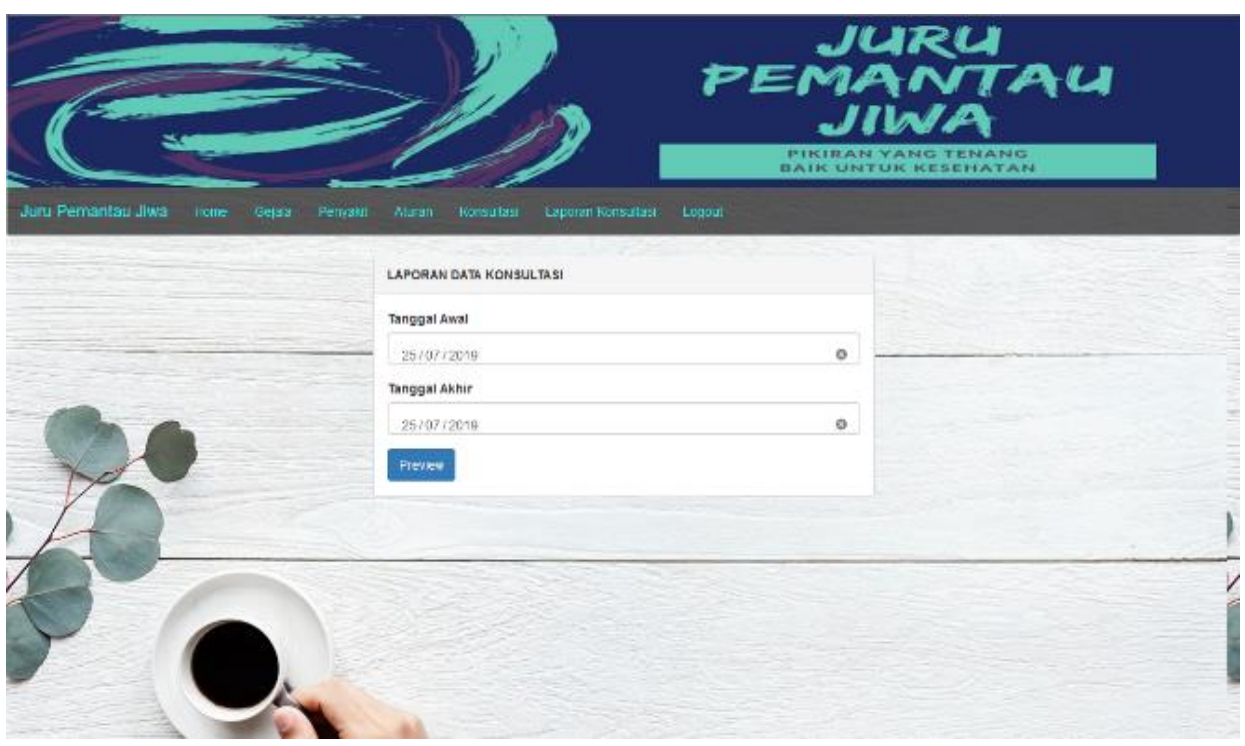

Sumber: Hasil Penelitian (2019)

Gambar 9. Tampilan Halaman Laporan (Admin)

Tampilan terakhir yaitu halaman laporan dimana admin dapat melihat dalam periode tertentu konsultasi pengunjung yang pernah dilakukan.

\section{Desain Sistem}

\section{Use Case Diagram}

Pada Gambar 12 dijelaskan use case diagram admin, sebagai berikut: satu admin dan enam use case terdiri dari use case gejala, use case penyakit, use case aturan, use case konsultasi, usecase laporan konsultasi, dan use case admin.

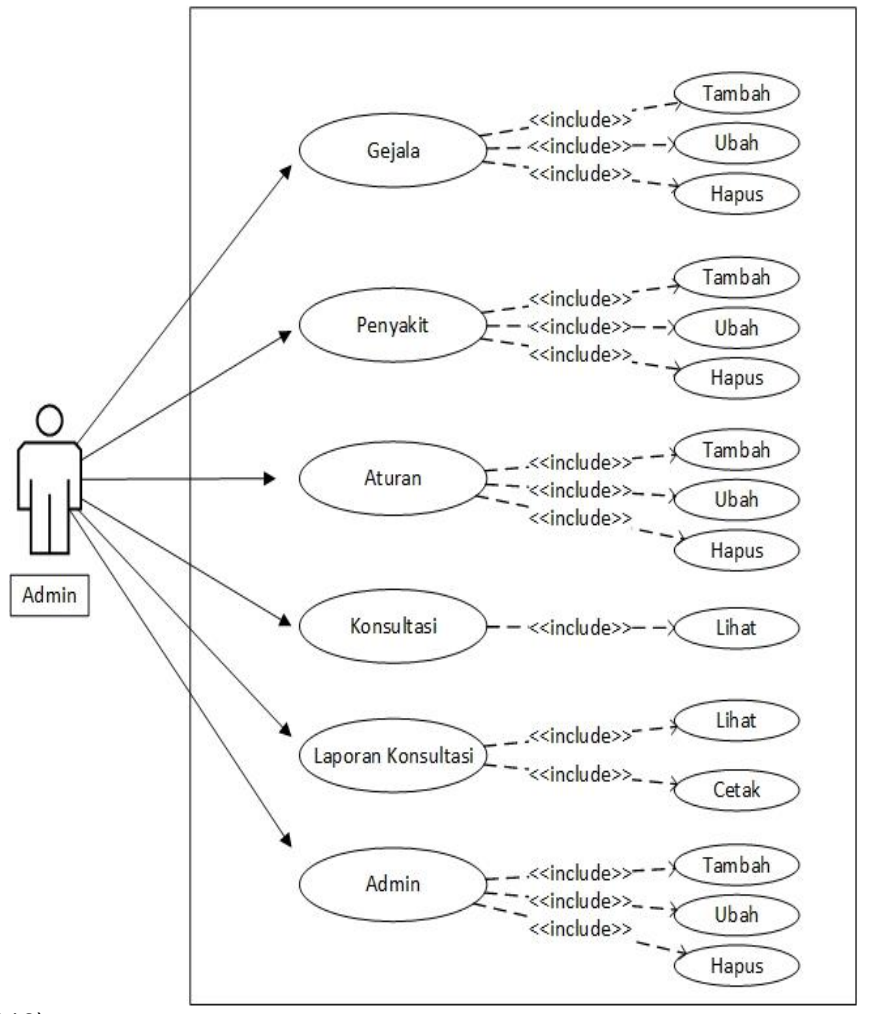

Gambar 12. Use Case Diagram Admin 
Sedangkan Gambar 13 menjelaskan use case diagram user dimana terdapat satu actor dan dua use case terdiri dari use case home dan use case konsultasi.

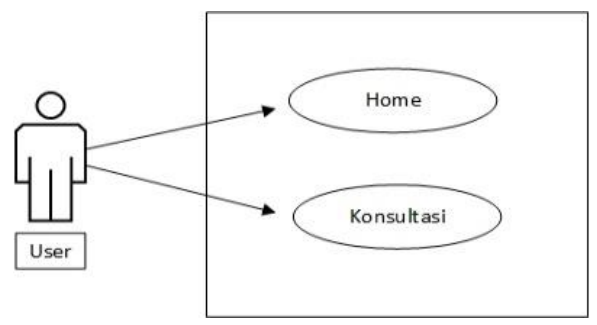

Sumber: Hasil Penelitian (2019)

Gambar 13. Use Case Diagram User

\section{Activity Diagram}

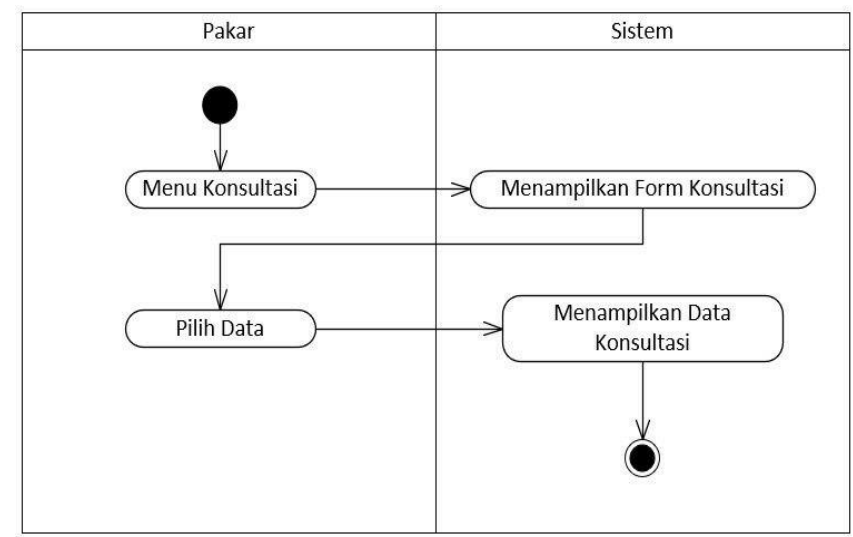

Sumber: Hasil Penelitian (2019)

Gambar 14. Activity Diagram Konsultasi

Pada Gambar 14 menjelaskan tentang Activity Diagram Konsultasi, dimulai dari Pakar memilih menu konsultasi, kemudian sistem menampilkan form konsultasi dilanjutkan dengan Pakar memilih data, dan sistem menampilkan data konsultasi.

3. Sequence Diagram

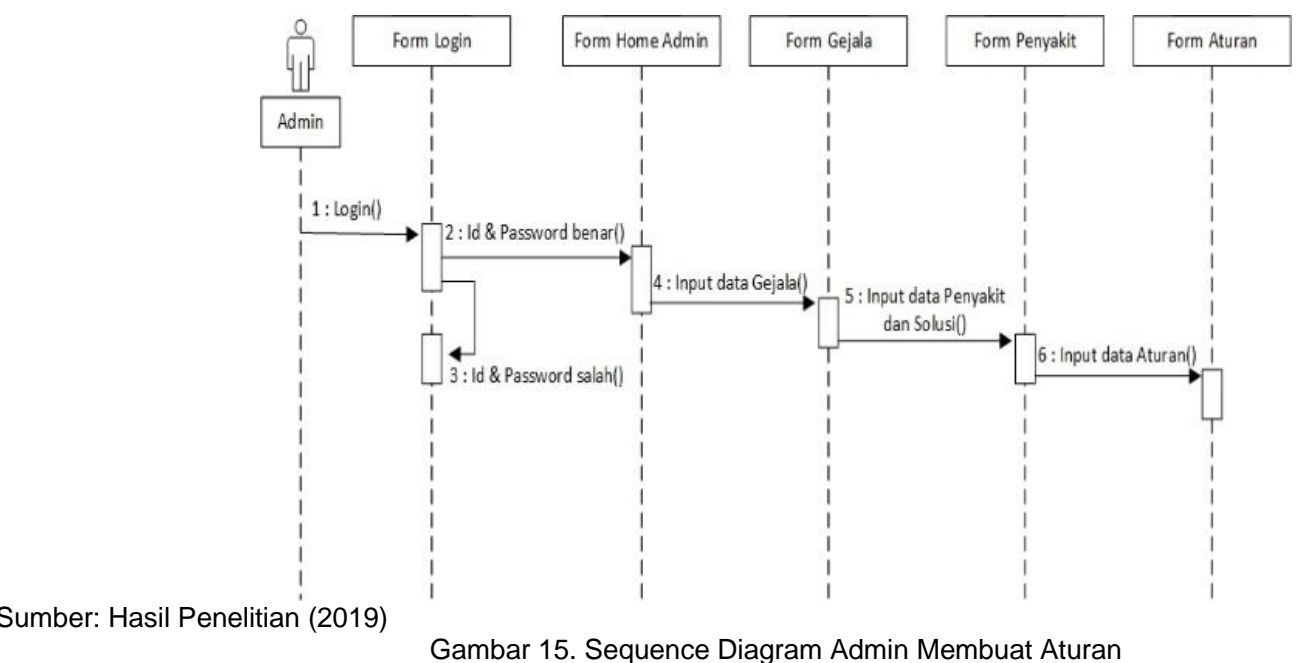

Pada Gambar 15 menjelaskan tentang Sequence Diagram admin membuat aturan, terdiri dari admin, form login, form home admin, form gejala, form penyakit, dan form aturan. 
Sumber: Hasil Penelitian (2019)

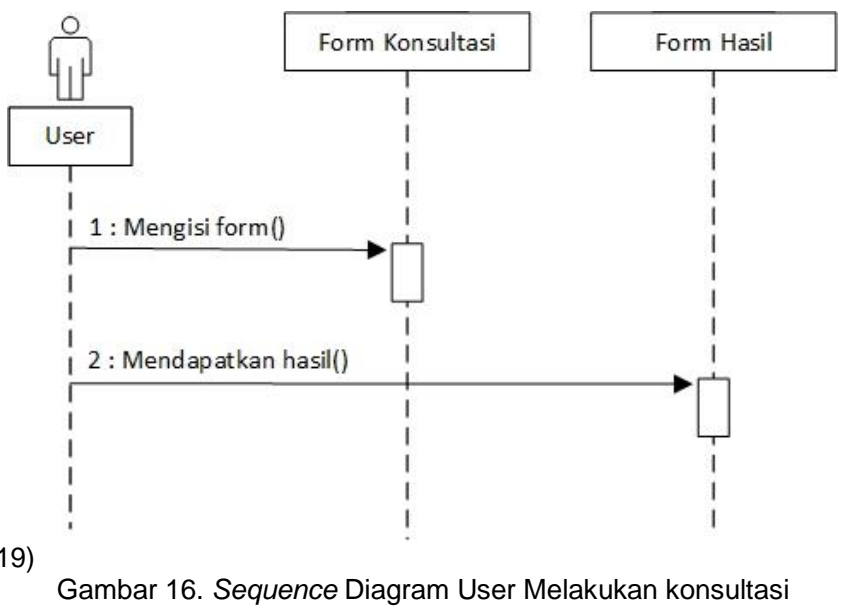

Pada Gambar 16 menjelaskan tentang sequence Diagram use melakukan konsultasi, terdiri dari user, form konsultasi dan form hasil.

\section{Kesimpulan}

Berdasarkan hasil penelitian dan pembahasan yang telah dilakukan, maka penulis dapat memberikan kesimpulan dengan adanya aplikasi sistem pakar ini sebagai sarana yang tepat dan praktis untuk berkonsultasi dengan pakar kejiwaan tanpa harus bertemu langsung dengan psikolog, menganalisa kondisi kejiwaan yang dialami pasien, sehingga dapat memilihalternatif langkah kerja dan mendapatkan solusi, mendapatkan edukasi tentang penyakit yang berhubungan dengan masalah kejiwaan.

\section{Daftar Pustaka}

Akil, I. (2017). Analisa Efektifitas Metode Forward Chaining Dan Backward Chaining Pada Sistem Pakar. Jurnal Pilar Nusa Mandiri, 13(1), 35-42. Retrieved From Http://Ejournal.Nusamandiri.Ac.Id/Index.Php/Pilar/Article/View/12

Juniawan, F. P. (2017). Penggunaan Metode Forward Chaining Dalam Perancangan Sistem Pakar Diagnosa Gangguan Kejiwaan. Jurnal Informatika Global, 8(1), 29-35. Retrieved From Http://Ejournal.Uigm.Ac.Id/Index.Php/lg/Article/View/220

Septiana, L. (2016). Perancangan Sistem Pakar Diagnosa Penyakit Ispa Dengan, Xiii(2).

Septianto, R., Informatika, M., \& Tasikmalaya, K. (2016). Sistem Pakar Diagnosis Kerusakan Pada Televisi ( Tv ) Tabung Menggunakan, Xiii(2), 52-63.

Studi, P., \& Informasi, S. (2015). Metode Forward Chaining Untuk Mendiagnosa, Xi(2), 197-202.

Surbakti, J., Kardian, A. R., Informasi, S., Gunadarma, U., Informasi, S., Sti, S. J., ... Kunci, K. (2016). Sistem Pakar Kejiwaan Dengan Forward Chaining Berbasis Web, 15, 23-33. 